University of Nebraska - Lincoln

DigitalCommons@University of Nebraska - Lincoln

$12-2000$

\title{
Effects of Roadside Transect Width on Waterfowl and Wetland Estimates
}

Jane E. Austin

U.S. Geological Survey, jaustin@usgs.gov

H. Thomas Sklebar

U.S. Geological Survey

Glenn R. Guntenspergen

U.S. Geological Survey, Glenn_Guntenspergen@usgs.gov

Thomas K. Buhl

U.S. Geological Survey, tbuhl@usgs.gov

Follow this and additional works at: https://digitalcommons.unl.edu/usgsnpwrc

Part of the Other International and Area Studies Commons

Austin, Jane E.; Sklebar, H. Thomas; Guntenspergen, Glenn R.; and Buhl, Thomas K., "Effects of Roadside Transect Width on Waterfowl and Wetland Estimates" (2000). USGS Northern Prairie Wildlife Research Center. 4.

https://digitalcommons.unl.edu/usgsnpwrc/4

This Article is brought to you for free and open access by the US Geological Survey at DigitalCommons@University of Nebraska - Lincoln. It has been accepted for inclusion in USGS Northern Prairie Wildlife Research Center by an authorized administrator of DigitalCommons@University of Nebraska - Lincoln. 


\title{
EFFECTS OF ROADSIDE TRANSECT WIDTH ON WATERFOWL AND WETLAND ESTIMATES
}

\author{
Jane E. Austin, H. Thomas Sklebar, Glenn R. Guntenspergen, ${ }^{1}$ and Thomas K. Buhl \\ U.S. Geological Survey \\ Northern Prairie Wildlife Research Center \\ Jamestown, North Dakota, USA 58401 \\ ${ }^{1}$ Present address: \\ U.S. Geological Survey \\ Patuxent Wildlife Research Center \\ Laurel, Maryland, USA 20708
}

\begin{abstract}
Strip transects located along roads are commonly used to estimate waterfowl populations and characterize associated wetland habitat. We used data collected in May and early June, 1995, on forty-five $40-\mathrm{km}^{2}$ plots in North Dakota to evaluate bias of $800-\mathrm{m}$ and $400-\mathrm{m}$ wide roadside transects for sampling wetlands relative to a larger $\left(40-\mathrm{km}^{2}\right)$ scale and to compare duck abundance at the two widths. Densities of all basins combined and of seasonal basins considered alone were biased high for both transect widths, but mean bias did not differ from zero for temporary or semipermanent basins. Biases did not occur when excavated seasonal and temporary basins (i.e., road ditches) were excluded from the sample. Mean basin density was higher for the inner $(400-\mathrm{m})$ transect width than for the outer transect width (area remaining of the 800-m transect, outside of center 400-m width) for all basins combined and for seasonal and temporary basins. We detected an area-related bias in the occurrence of basins in transects: smaller basins (0.08-1.6 ha) were over-represented in transect samples by $2.9-6.5 \%$, and larger basins ( $\geq 11$ ha) were under-represented in $800-\mathrm{m}$ transects by $7.3 \%$ and in $400-\mathrm{m}$ transects by $16.3 \%$. We compared the distribution of ducks relative to water conditions in the inner and outer transect widths to evaluate whether they were affected by proximity to the road. Mallards (Anas platyrhynchos L.), northern pintails (A. acuta L.), and gadwall (A. strepera L.) responded to water conditions equally in the inner and outer transect widths, but northern shovelers (A. clypeata L.) and blue-winged teal (A. discors L.) responded more strongly to wetlands on the inner than the outer transect width, indicating that estimates of these species would be higher from a 400$\mathrm{m}$ wide transect than from an 800-m wide transect. Differences in an adjustment index, used to account for the portion of basin obscured from view, were highly variable between inner and outer transect widths but did not indicate that use of wider transects was hampered by visibility. Biases of transect sampling need to be carefully considered when extrapolating wetland basin or duck densities from transects to larger landscape scales.
\end{abstract}

Key Words: bias, North Dakota, roadside transect, sampling, waterfowl

\section{INTRODUCTION}

Strip transects commonly are used to evaluate waterfowl populations and associated wetland habitat at local (Dzubin 1969, Serie and Cowardin 1990, Arnold 1994), state (state waterfowl surveys), and regional scales (Waterfowl Breeding Population and Habitat Surveys [WBPHS]; U.S. Fish and Wildlife Service and Canadian Wildlife Service 1987, Cowardin and Blohm 1992). Often, strip transects are located along roads to permit rapid and easy access to large areas. Roadside transects have been a particularly valuable tool in the Prairie Pothole Region of North America because of systematic distribution of roads over much of the region. Roadside transects eliminate need for landowner permission for access (Fellows and Buhl 1995). Although the roadside transect is a well-established method, there have been few assessments of its potential biases relative to larger landscape scales in terms of wetlands or waterfowl sampled. Johnson and Higgins (1998) and Johnson et al. (1999) assessed quadrat and strip transects for estimating wetland numbers but did not evaluate potential bias of wetland basin area or duck numbers. Geographic information systems (GIS) provide the opportunity to more accurately assess bias in wetland basin characteristics in transect samples and how such biases may affect waterfowl estimates.

Roadside strip transects are usually $400 \mathrm{~m}$ (0.25 mi) in width (i.e., $200 \mathrm{~m}$ [0.125 mi] either side of the cen- 


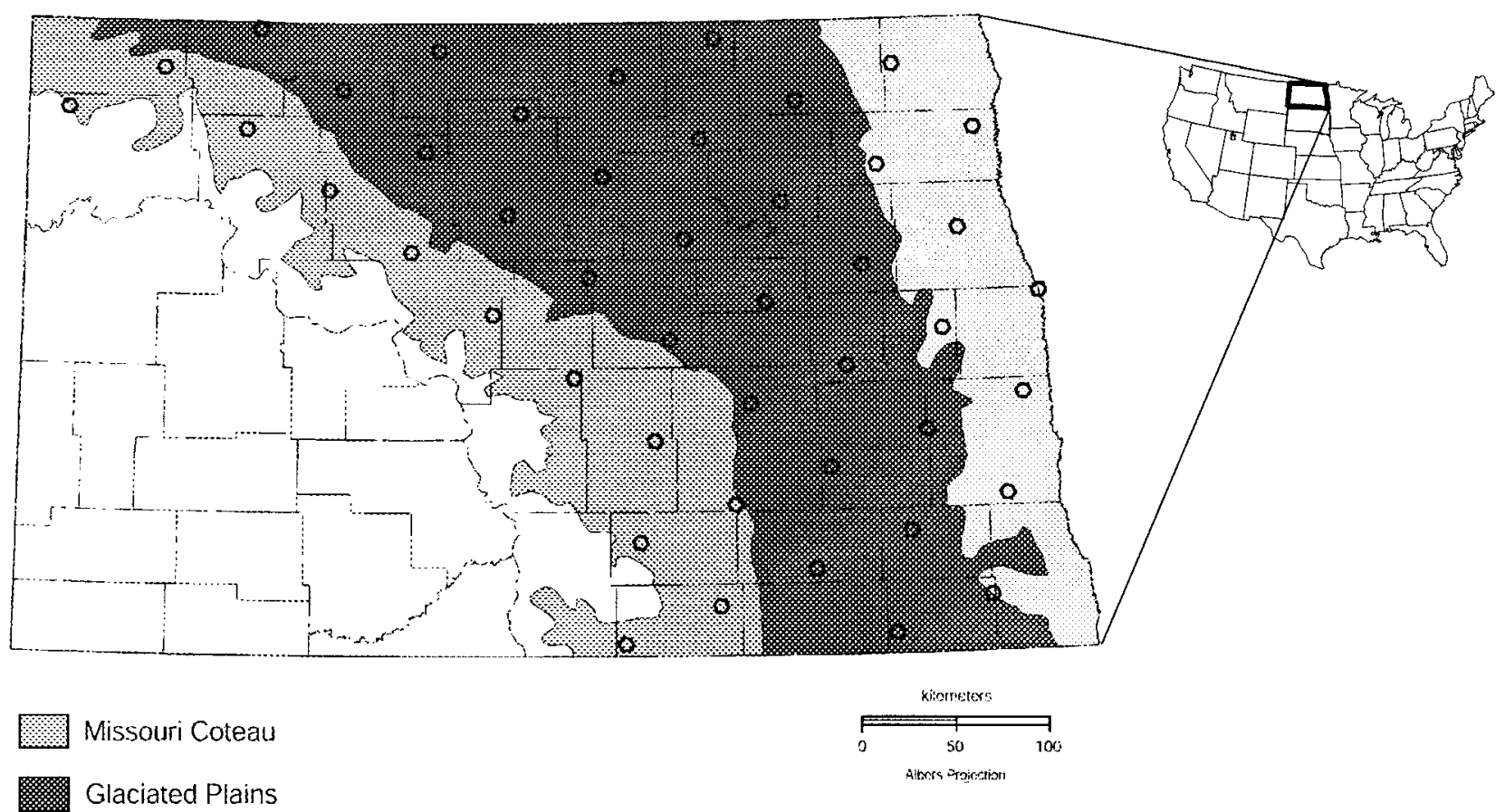

Red River Valley

Figure 1. Location of forty-five 40-km² plots in North Dakota, 1995.

ter of the right-of-way) (e.g., Dzubin 1969, Serie and Cowardin 1990; North Dakota waterfowl surveys, M. Johnson, North Dakota Game and Fish Department, pers. comm.). This also is the width used in annual WBPHS in the U.S. and Canada (U.S. Fish and Wildlife Service and Canadian Wildlife Service 1987). We anticipated that a wider transect (e.g., $800 \mathrm{~m}$ [0.5 mi] wide, or $400 \mathrm{~m}$ on either side of the center of the road) would have less sample bias for wetland characteristics and would provide better duck estimates because a larger proportion of the landscape is sampled and larger wetlands would be more likely to be included. Wider transects also would include more area that is less impacted by the right-of-way (e.g., drainage of wetlands, vehicular disturbance to ducks). We are not aware of any studies that have examined whether duck distribution is affected by distance from a road.

We had the opportunity to examine these issues using data collected during the Environmental Monitoring and Assessment (EMAP) study (Austin et al. 2001). Data on wetland basins and ducks were collected using GIS and roadside transects, $800 \mathrm{~m}$ wide, on forty-five $40-\mathrm{km}^{2}$ plots systematically located across the Prairie Pothole Region portion of North Dakota, USA. The objectives of this paper are to address the following questions. (1) Did 800-m and 400-m wide transects provide unbiased measures of wetland characteristics of the larger sampling unit (plot)? (2) Did the two transect widths result in equivalent esti- mates of dabbling duck abundance? (3) Were wider transects logistically feasible in this region for waterfowl surveys? We discuss the biases and benefits of using 800-m versus 400-m transects for surveys of waterfowl and their associated wetland habitat.

\section{METHODS}

\section{Wetland Basin Data}

EMAP systematically divided North America using a grid of $40-\mathrm{km}^{2}$ hexagons. From this sample universe, we selected as study plots the 45 hexagons in North Dakota east of the Missouri River (Figure 1). Original base maps and geographic information coverages included National Wetlands Inventory (NWI) wetland data collected during 1979-82. Wetland basins were derived from NWI polygons using ARC-INFO macro language that combined polygons based on deepest water regime similar to methods used by Johnson and Higgins (1997). These coverages were updated using 1995 aerial photography, ground truthing, and data from the Department of Agriculture's Natural Resources Conservation Service. Processing of point and linear basins followed procedures in Cowardin et al. (1995). Area of each basin was determined from NWI vector coverage and rounded to the nearest 0.01 ha.

Roadside transects were located along all roads drivable in May 1995 in each study plot. The 800-m road- 


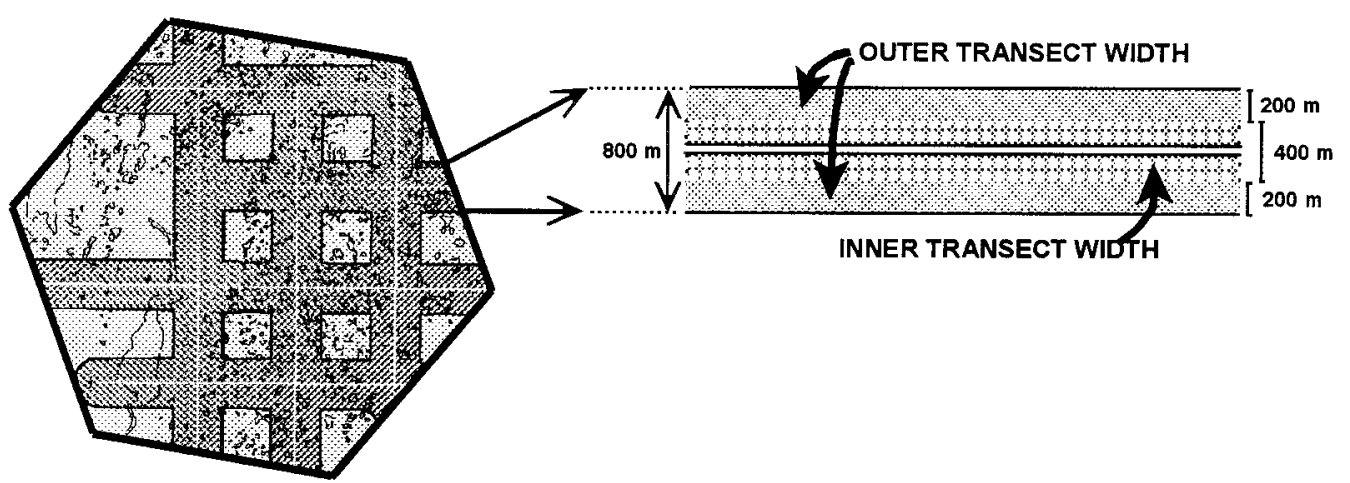

Figure 2. Representation of transect and transect width samples for $40-\mathrm{km}^{2}$ plots.

side transect included all basins within $400 \mathrm{~m}$ on either side of the center of the road. The 400-m transect included basins $200 \mathrm{~m}$ on either side of the center of the road. We also examined the $800-\mathrm{m}$ transect as two smaller subsamples: the 400-m transect, also referred to as the inner transect width, and remaining area of the 800-m width, or outer transect width (Figure 2). Basins were included in a transect sample if their centroids fell within the transect boundaries.

\section{Duck Population Estimates}

Basins at least partially observable from the road right-of-way constituted the sample of wetland basins in each study area for duck counts. We used an optimal allocation to select a stratified random subsample of 100 basins from each transect area; we treated the basin water regimes (temporary, seasonal, semipermanent, permanent) as strata to obtain a sample throughout the range of basin sizes and to avoid oversampling small basins (Cowardin et al. 1995:4). All basins were sampled if there were less than 100 basins in the transect. When we were unable to view a basin, we replaced it with a basin of the same regime that was located within the 800-m transect area.

We conducted duck counts from vehicles along each right-of-way. For each basin sampled, we recorded number of ducks by species and social groups (Cowardin et al. 1995) and ocularly estimated the proportion of the basin that could be observed, the proportion of the basin that was not obstructed by emergent vegetation, and areal percent of basin holding water. Ducks counted on each basin were later adjusted to account for the portion of the wetland that could be observed, assuming that ducks were dispersed equally across the basin:

$$
\text { DUCKADJ }=\frac{[\text { BREEDPOP } /(\text { PERCOUNT })]}{[(\text { BASINT/10 }+0.05)]}
$$

where
DUCKADJ

$=$ adjusted duck count,

BREEDPOP

$=$ number of breeding duck pairs counted on a basin,

\section{PERCOUNT}

$=$ percent of the basin that could be viewed (i.e., not obscured by topography or structures; to nearest 5\%), and

\section{BASINT}

$=$ viewable proportion of the basin that was not obstructed by emergent vegetation (classified as 0 [0-10\%] to 9 [90-100\%]; 0.05 added to prevent division by 0 ).

Two counts were conducted each year. Data from early counts (1-15 May) were used to estimate breeding pairs of mallards (Anas platyrhynchos L.) and northern pintails (A. acuta L.) whereas data from late counts (20 May-5 June) were used to estimate breeding pairs of blue-winged teal (A. discors L.) and gadwall (A. strepera L.) (Cowardin et al. 1988). Breeding pairs of northern shovelers (A. clypeata) were estimated from the count occurring nearest 15 May. We assigned the adjusted duck data for each basin to 400$\mathrm{m}$ (inner) and outer transect samples using unique basin identifying numbers.

\section{Data Analyses}

We limited our wetland data analyses to temporary, seasonal, and semipermanent wetland regimes (Cowardin et al. 1979). Other regimes (e.g., permanent, riverine) were uncommon in most plots.

Wetland Characteristics. We calculated bias as the difference between basin density $\left(\mathrm{no} . / \mathrm{km}^{2}\right)$ in the sample (800-m or 400-m transect) and that in each plot, for all basins combined and for each water regime. 
Bias also was expressed as percent of plot density. Confidence intervals $(95 \%)$ around the mean difference not including zero were interpreted as significant bias.

Roadside transects provide unbiased estimates of wetland densities only when wetland basins are randomly distributed. To determine the extent of bias resulting from non-random distributions of wetland basins, we partitioned wetlands into size classes and, for each size class, compared the number of basin centroids included in transects with the number expected under the hypothesis of random distribution. Size classes were created by partitioning square roots of wetland areas into equal-width intervals on a natural log scale because small basins were much more abundant than large ones.

Duck Counts and Adjustment Index. To address whether 800-m and 400-m transects provided equivalent measures of duck abundance, we needed to take into account differences in wetland characteristics reflective of available water (basin densities and area) in the two transect widths. First, we used baseline pair regressions developed for each species by Cowardin et al. (1995) to determine predicted number of ducks, given the wetland conditions present, for the $800-\mathrm{m}$ width and for inner (400-m) and outer transect widths of each plot:

$$
\text { PREDICTED }=\mathrm{A} * \text { AWET }+\mathrm{B} * V(\text { AWET })
$$

where $\mathrm{A}$ and $\mathrm{B}$ are regression coefficients used for estimating indicated pairs defined by Cowardin et al. (1995), by species, and AWET is water area of each basin (ha), determined from May aerial photography (Austin et al. 2001). We weighted DUCKADJ on each basin so that those basins that had a larger portion of their area viewable for ducks, as measured by PERCOUNT and BASINT, received greater weight than those basins that had a lower portion viewable. We set this correction for viewability as:

$$
\text { VCORR }=[\text { PERCOUNT } *(\text { BASINT/10 }+0.05)]
$$

Then the weighted duck count is:

$$
\text { DUCKADJ }=\text { BREEDPOP/VCORR. }
$$

Duck estimates from these baseline regression curves are based on the assumption that densities of ducks on ponds of the same size remains constant among years and among areas. Therefore, we corrected those curves using $\gamma$ to reflect specific local conditions (duck numbers and water areas); $\gamma$ is calculated as the number of ducks counted on an area divided by the number predicted given those wetland conditions (see Cowardin et al. 1995). We used $\gamma$ as our measure of duck response in each transect width; a $\gamma$ greater than 1.0 indicates more ducks were present than expected whereas a $\gamma$ less than 1.0 indicates fewer ducks were present than expected. The weight used in calculating $\gamma$ is:

$$
\text { WEIGHT }=(\text { VCORR } \times \mathrm{N}) / \sum(\text { VCORR })
$$

where

$\mathrm{N}=$ number of basins of each water regime

(Cowardin et al. 1979) in each transect sample.

For each species, we calculated $\gamma$ for each water regime, using weighted DUCKADJ, for each transect sample:

$$
\gamma=\frac{\sum(\text { DUCKADJ } \times \text { WEIGHT })}{\sum(\text { PREDICTED })} .
$$

This measure effectively adjusts the predicted regression curve to account for annual and spatial differences in duck populations and wetlands using observed data. We then calculated the difference in the means of $\gamma$ between inner and outer transects. No difference in $\gamma$ between the inner and outer transect widths would indicate that ducks responded equally to water conditions in both areas. Confidence intervals (95\%) around the mean difference not including zero were interpreted as significant difference.

We also analyzed whether indices used to adjust duck counts (percent of basin that could be viewed and percent of basin not obscured by emergent vegetation) differed between inner and outer transect widths (i.e., were we able to count ducks on a larger portion of a basin when a basin was closer to the road?). We set number of ducks counted (BREEDPOP) equal to one in the DUCKADJ formula to yield a single index for each count (hereafter referred to as adjustment index); the adjustment index increased as the portion of the basin that could be observed for counting ducks decreased. We calculated the difference between the indices occurring in the inner and outer transect widths for each plot. Confidence intervals $(95 \%)$ around the mean difference not including zero were interpreted as a significant difference between inner and outer transect widths. Because ducks were counted twice in May-early June, and we anticipated that adjustment indices would be higher in late May-early June due to vegetation growth, we examined differences for each count separately.

Feasibility of Viewing Basins. We had to replace some basins that had been selected in the original sample because they could not be observed from the road. We determined the proportion of basins that occurred in the inner and outer transect widths of the original sample that were replaced. We calculated the difference in proportion replaced between the two widths; 
Table 1. Basin densities (mean $\pm \mathrm{SE}$ ) and bias (mean $\pm \mathrm{SE}$; range in parentheses) for $40-\mathrm{km}^{2}$ plots and $800-\mathrm{m}$ and $400-\mathrm{m}$ wide transects, for 45 plots in North Dakota using NWI data. Bias is calculated as the difference between basin density on transect and that on the plot. Biases with $95 \%$ confidence intervals not including zero are highlighted in bold.

\begin{tabular}{|c|c|c|c|c|}
\hline \multirow{2}{*}{$\begin{array}{c}\text { Basin } \\
\text { Water Regime }\end{array}$} & \multirow[b]{2}{*}{ Sample } & \multirow{2}{*}{$\begin{array}{l}\text { Basin Density } \\
\text { (No./Ha) }\end{array}$} & \multicolumn{2}{|c|}{ Bias } \\
\hline & & & No./Ha & $\%$ Plot Density \\
\hline \multirow[t]{3}{*}{ Temporary } & Plot & $0.0647 \pm 0.0085$ & & \\
\hline & $800 \mathrm{~m}$ & $0.0657 \pm 0.0085$ & $0.0010 \pm 0.0007$ & $1.5 \pm 1.1$ \\
\hline & $400 \mathrm{~m}$ & $0.0657 \pm 0.0083$ & $0.0011 \pm 0.0014$ & $1.7 \pm 2.2$ \\
\hline \multirow[t]{3}{*}{ Seasonal } & Plot & $0.0694 \pm 0.0065$ & & \\
\hline & $800 \mathrm{~m}$ & $0.0735 \pm 0.0069$ & $0.0041 \pm 0.0012$ & $5.9 \pm 1.7$ \\
\hline & $400 \mathrm{~m}$ & $0.0842 \pm 0.0078$ & $0.0148 \pm 0.0022$ & $21.3 \pm 3.2$ \\
\hline \multirow[t]{3}{*}{ Semipermanent } & Plot & $0.0094 \pm 0.0011$ & & \\
\hline & $800 \mathrm{~m}$ & $0.0096 \pm 0.0012$ & $0.0001 \pm 0.0002$ & $1.1 \pm 2.1$ \\
\hline & $400 \mathrm{~m}$ & $0.0096 \pm 0.0014$ & $0.0002 \pm 0.0004$ & $2.1 \pm 4.3$ \\
\hline \multirow[t]{3}{*}{ All basins } & Plot & $0.1435 \pm 0.0135$ & & \\
\hline & $800 \mathrm{~m}$ & $0.1487 \pm 0.0138$ & $0.0052 \pm 0.0017$ & $3.5 \pm 1.2$ \\
\hline & $400 \mathrm{~m}$ & $0.1597 \pm 0.0146$ & $0.0161 \pm 0.0028$ & $11.2 \pm 2.0$ \\
\hline
\end{tabular}

${ }^{\mathrm{a}}$ Bias (no./ha) expressed as a percentage of plot density.

proportions were first transformed using a square-root transformation. Confidence intervals around the mean difference not including zero were interpreted as significant differences.

\section{RESULTS}

Roads were limited in some plots, and in other plots travel along roads was restricted due to flooding, cultivation, or other conditions. The percent of the 40$\mathrm{km}^{2}$ plot area encompassed by $800-\mathrm{m}$ transects averaged $63.2 \pm 9.0 \%$ (SD) (range 38.7-76.9\%). Percent of plot area encompassed by 400-m transects averaged $35.7 \pm 6.4 \%$ (range $20.0-47.2 \%$ ). Length of roads accessible for transect surveys varied from 14.7 to 70.1 $\mathrm{km}(\overline{\mathrm{x}}=41.0 \pm 9.8 \mathrm{~km}[\mathrm{SD}])$. Proportional coverages cannot be directly derived by multiplying transect lengths by widths because of overlap in transect widths where roads intersect and varying size of some plots (plots overlaying North Dakota border included only area within the state).

\section{Wetland Basin Characteristics}

Basin Density. Total basin density in transects was usually higher than that in the entire plot (positive bias on 39 of 45 plots for $800-\mathrm{m}$ transects and 40 of 45 plots for 400-m transects). Densities of all basins and of seasonal basins were biased high for both transect widths, but mean bias did not differ from zero for temporary or semipermanent basins (Table 1). Except for temporary basins, mean bias was at least twice as high for 400-m transects as for 800-m transects, suggesting that basin density was greater on the transect width closest to roads. Mean bias of $800-\mathrm{m}$ transects was $\leq 4 \%$ of plot density for all regimes, whereas mean bias for $400-\mathrm{m}$ transects was $+11 \%$ for all basins, primarily due to the high bias for seasonal basins (21\%). Bias for individual plots was usually within $\pm 10 \%$ of plot density but on some plots was $> \pm 20 \%$. Scatter plots showed no patterns of bias relative to basin density on plots or to proportion of plot sampled by the transect. Examination of biases graphically summarized by geographic region (Red River Valley, Drift Plain, and Coteau) showed no patterns.

When we excluded excavated temporary and seasonal basins (primarily roadside ditches), biases were not significant (Table 2). Mean bias for all wetlands was $+0.8 \%$ of plot density for all regimes in $800-\mathrm{m}$ transects and $+2.8 \%$ for $400-\mathrm{m}$ transects. Although nonsignificant, mean bias again was highest for seasonal wetlands in $400-\mathrm{m}$ transects $(+5.5 \%$ of plot density).

Mean basin density was greater for the inner transect width than for the outer transect width for all basins combined and for seasonal and temporary basins (Table 3). Differences were largest for seasonal basins $(+0.0311$ basins/ha or $42.3 \%$ of plot density), which comprised on average about $50 \%$ of basins in the plots; only two plots had higher densities of seasonal basins on the outer transect width.

Basin Area. We detected an area-related bias in the occurrence of basins in transect samples (Figure 3). Basins averaging 0.01 ha in size $(n=112)$ were overrepresented by $14.3 \%$ on $400-\mathrm{m}$ transect samples and slightly under-represented (-0.7\%) on 800-m transects. Biases were $<1 \%$ for basins averaging 0.02 ha in size $(\mathrm{n}=5,420)$ for either transect width. Basins averaging $0.08,0.35$, and 1.6 ha were over-represented on both 
Table 2. Basin densities (mean $\pm \mathrm{SE}$ ) and bias (mean $\pm \mathrm{SE}$; range in parentheses) for $40-\mathrm{km}^{2}$ plots and 800 - $\mathrm{m}$ and $400-\mathrm{m}$ wide transects, when excavated seasonal and temporary wetlands are excluded, for 45 plots in North Dakota, using NWI data. Bias is calculated as the difference between basin density on transect and that on the plot. All 95\% confidence intervals for biases included zero.

\begin{tabular}{|c|c|c|c|c|}
\hline \multirow{2}{*}{$\begin{array}{c}\text { Basin } \\
\text { Water Regime }\end{array}$} & \multirow[b]{2}{*}{ Sample } & \multirow{2}{*}{$\begin{array}{c}\text { Basin Density } \\
\text { (No./Ha) }\end{array}$} & \multicolumn{2}{|c|}{ Bias } \\
\hline & & & No./Ha & $\%$ Plot Density \\
\hline \multirow[t]{3}{*}{ Temporary } & Plot & $0.0639 \pm 0.0085$ & & \\
\hline & $800 \mathrm{~m}$ & $0.0646 \pm 0.0084$ & $0.0007 \pm 0.0007$ & $1.1 \pm 1.1$ \\
\hline & $400 \mathrm{~m}$ & $0.0641 \pm 0.0082$ & $0.0001 \pm 0.0013$ & $0.2 \pm 2.0$ \\
\hline \multirow[t]{3}{*}{ Seasonal } & Plot & $0.0618 \pm 0.0062$ & & \\
\hline & $800 \mathrm{~m}$ & $0.0622 \pm 0.0064$ & $0.0004 \pm 0.0012$ & $0.6 \pm 1.9$ \\
\hline & $400 \mathrm{~m}$ & $0.0652 \pm 0.0069$ & $0.0034 \pm 0.0019$ & $5.5 \pm 3.1$ \\
\hline \multirow[t]{3}{*}{ All basins } & Plot & $0.1257 \pm 0.0124$ & & \\
\hline & $800 \mathrm{~m}$ & $0.1268 \pm 0.0124$ & $0.0010 \pm 0.0017$ & $0.8 \pm 1.4$ \\
\hline & $400 \mathrm{~m}$ & $0.1292 \pm 0.0145$ & $0.0035 \pm 0.0027$ & $2.8 \pm 21.8$ \\
\hline
\end{tabular}

${ }^{a}$ Bias (no./ha) expressed as a percentage of plot density.

transect widths, with somewhat higher bias on 400-m transects $(0.08$-ha basins [ $\mathrm{n}=8,784]$ : over represented by $2.9 \%$ and $5.0 \%$ for $800-\mathrm{m}$ and $400-\mathrm{m}$ transects, respectively; 0.35-ha basins [n $=9,402]$ : over represented by $3.6 \%$ and $6.5 \% ; 1.60$-ha basins $[\mathrm{n}=1,599]$ : $1.7 \%$ and $3.3 \%$ ). Bias was near zero for basins averaging 4.25 ha in size $(0.1$ and $-1.9 \%$, respectively; $n$ $=569$ ). Biases differed most strongly between transect widths for basins $>10$ ha, although samples sizes of these larger wetlands quickly degraded. Basins averaging 11.68 ha in size $(n=159)$ were under-represented on $800-\mathrm{m}$ transects by $7.3 \%$ and on $400-\mathrm{m}$ transects by $16.3 \%$. Our plots included only 12 basins averaging 31.73 ha in size; these were under-represented on $800-\mathrm{m}$ transects by $7.6 \%$ and in $400-\mathrm{m}$ transects by $20.5 \%$. Fourteen wetlands fell in size categories larger than this, but very small sample sizes limited meaningful comparisons of bias.

\section{Duck Counts and Adjustment Index}

Differences in Indicated Pairs. Differences in $\gamma$ were significant for shovelers and blue-winged teal but not for mallards, pintails, or gadwall (Table 4). Shovelers and blue-winged teal had higher $\gamma$ in the inner transect width, indicating more of these species occurred on the inner transect width than on the outer transect width, given the wetland conditions on each area.

Differences in Adjustment Index. Although the mean adjustment index usually was higher in the outer transect width, mean differences did not differ from zero except for all basins combined in the first count and seasonal and temporary wetlands in the second count (Table 5). Increases in the adjustment index from the first to the second count was greatest in the outer transect width.

\section{Feasibility of Sampling Basins}

For counting ducks, we had to replace an average of $19 \%$ of basins originally selected (Table 6). Replacements were made by observers in the field, who selected the next basin of the same regime that could be sampled from the road. There was no difference in

Table 3. Basin density (mean $\pm \mathrm{SE}$, range) on inner and outer transect widths, and difference between the inner and outer transect widths (mean $\pm \mathrm{SE}$; range in parentheses) for 45 plots in North Dakota, using NWI data. Differences highlighted in bold indicate those differences with $95 \%$ confidence intervals that do not include zero.

\begin{tabular}{|c|c|c|c|c|c|}
\hline \multirow{2}{*}{$\begin{array}{c}\text { Basin } \\
\text { Water Regime }\end{array}$} & \multirow{2}{*}{$\begin{array}{c}\text { Inner Transect } \\
\text { Width }\end{array}$} & \multirow{2}{*}{$\begin{array}{c}\text { Outer Transect } \\
\text { Width }\end{array}$} & \multirow{2}{*}{$\begin{array}{l}\text { Mean Difference } \\
\text { (Inner-Outer) }\end{array}$} & \multicolumn{2}{|c|}{ No. Plots } \\
\hline & & & & Inner $>$ Outer & Outer $>$ Inner \\
\hline Temporary & $\begin{array}{l}0.0657 \pm 0.0083 \\
(0.0026,0.2644)\end{array}$ & $\begin{array}{c}0.0571 \pm 0.0078 \\
(0,0.2629)\end{array}$ & $\begin{array}{c}\mathbf{0 . 0 0 8 6} \pm \mathbf{0 . 0 0 2 4} \\
(-0.0290,0.0565)\end{array}$ & 33 & 12 \\
\hline Seasonal & $\begin{array}{l}0.0843 \pm 0.0078 \\
(0.0032,0.2340)\end{array}$ & $\begin{array}{c}0.0532 \pm 0.0059 \\
(0,0.2205)\end{array}$ & $\begin{array}{c}\mathbf{0 . 0 3 1 1} \pm \mathbf{0 . 0 0 3 7} \\
(-0.0030,0.0977)\end{array}$ & 43 & 2 \\
\hline Semipermanent & $\begin{array}{c}0.0096 \pm 0.0014 \\
(0.0006,0.0422)\end{array}$ & $\begin{array}{c}0.0084 \pm 0.0010 \\
(0,0.0295)\end{array}$ & $\begin{array}{c}0.0012 \pm 0.0008 \\
(-0.0089,0.0208)\end{array}$ & 26 & 19 \\
\hline All basins & $\begin{array}{c}0.1597 \pm 0.0146 \\
(0.0084,0.4335)\end{array}$ & $\begin{array}{c}0.1188 \pm 0.0118 \\
(0.0029,0.3374)\end{array}$ & $\begin{array}{c}\mathbf{0 . 0 4 0 9} \pm \mathbf{0 . 0 0 4 9} \\
(-0.0131,0.1069)\end{array}$ & 43 & 2 \\
\hline
\end{tabular}




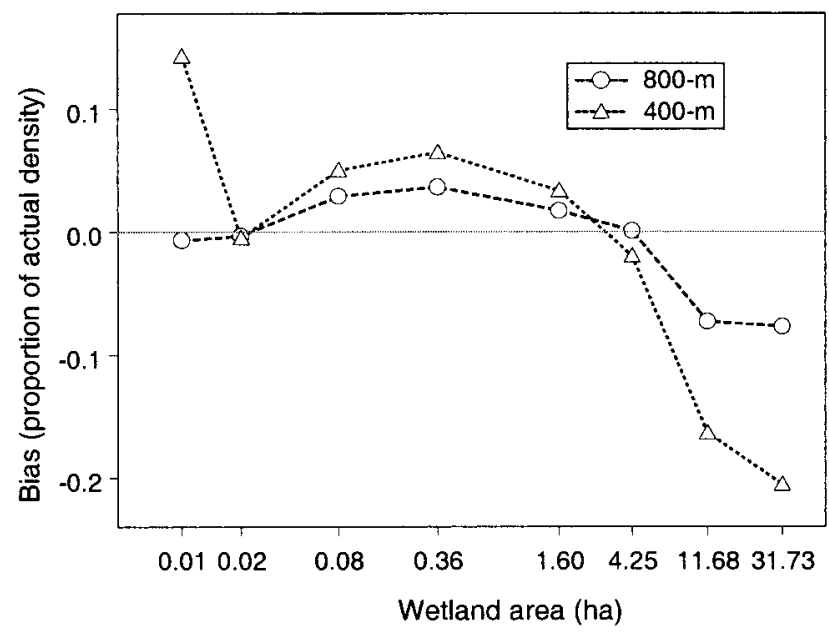

Figure 3. Bias in wetland densities as a function of wetland area for $800-\mathrm{m}$ and $400-\mathrm{m}$ wide roadside transects. Bias is expressed as a proportion of actual density in 45 plots in North Dakota, 1995.

proportion of basins that had to be replaced between inner and outer transect widths.

\section{DISCUSSION}

Roadside strip transects provided a positively biased representation of wetland basin density, primarily due to over-representation of seasonal basins. Biases often were greater in 400-m transects than in 800-m transects. Our results indicate that the distribution of basins was biased most strongly on the transect width closest to the road. However, density bias in both transect samples disappeared when we excluded excavated seasonal and temporary basins (primarily roadside ditches). Early in our consideration of whether strip transects along roads would provide unbiased representation of a larger universe, we had conceived two alternative hypotheses. First, we hypothesized that basin density, particularly that for seasonal and temporary wetlands, would be lower adjacent to roads because roadside ditches would provide a convenient drainage outlet for these more ephemeral basins (Kiel et al. 1972). Alternatively, we hypothesized that the construction of road rights-of-way would create new excavated basins (ditches) as well as split some basins into several basins; this would result in higher basin densities along roads. Indeed, basin densities in the inner transect width were higher, largely due to excavated basins, many of which likely were created by construction of the road bed. On average, $>90 \%$ of excavated temporary and seasonal wetlands occurred in 800-m transects, and of these, about $95 \%$ occurred within the inner transect width.

A second bias inherent in strip transect sampling is that related to area of basins that can be included within a certain width. Basin area-related bias was relatively moderate $(<7 \%)$ except for basins larger than about 10 ha. Of the 26,179 temporary, seasonal, and semipermanent basins in our sample, only 157 (0.6\%) were $\geq 10$ ha; basin size averaged $0.53 \pm 3.23$ (SD) ha. Thus, area-related bias for large wetlands would not be a significant concern in North Dakota but might be of greater concern where there are more large wetlands (e.g., western Minnesota). Area bias was greatest for narrower transects, as expected. Road development itself is a factor involved in the under-representation of basins because roads are often built across parts of a basin, unless it is very deep, creating two smaller basins. For strip transects that are not bisected by a road bed, area-related bias may be reduced, and size

Table 4. Mean $\gamma$ (mean $\pm \mathrm{SE}$ ), a correction factor that takes into account variation in basin densities and area, for 800-m and 400-m transects and for the outer transect width, and difference between inner (400-m transect) and outer transect widths (mean \pm SE; range in parentheses) for 41 plots in North Dakota, 1995. Significant $(P<0.05)$ differences are highlighted in bold. $\mathrm{N}=$ number of plots.

\begin{tabular}{|c|c|c|c|c|c|c|}
\hline \multirow[b]{2}{*}{ Species } & \multicolumn{3}{|c|}{$\gamma$} & \multirow[b]{2}{*}{$\begin{array}{l}\text { Mean Difference } \\
\text { (Inner-Outer) }\end{array}$} & \multicolumn{2}{|c|}{ No. Plots } \\
\hline & $\begin{array}{l}\text { 800-m } \\
\text { Transect }\end{array}$ & $\begin{array}{c}\text { 400-m Transect } \\
\text { (Inner Transect } \\
\text { Width) }\end{array}$ & Outer Width & & $\begin{array}{c}\text { Inner }> \\
\text { Outer }\end{array}$ & $\begin{array}{c}\text { Outer }> \\
\text { Inner }\end{array}$ \\
\hline $\begin{array}{l}\text { Mallard } \\
\qquad(\mathrm{N}=38)\end{array}$ & $2.5071 \pm 0.4685$ & $2.5718 \pm 0.5149$ & $2.5705 \pm 0.5250$ & $\begin{array}{c}0.0013 \pm 0.5078 \\
(-4.9130,14.8349)\end{array}$ & 13 & 22 \\
\hline $\begin{array}{l}\text { Pintail } \\
\qquad(\mathrm{N}=38)\end{array}$ & $1.8884 \pm 0.4535$ & $2.0308 \pm 0.5114$ & $1.7809 \pm 0.5246$ & $\begin{array}{c}(0.2499 \pm 0.6382 \\
(-7.9660,15.9057)\end{array}$ & 16 & 17 \\
\hline $\begin{array}{l}\text { Gadwall } \\
\qquad(\mathrm{N}=39)\end{array}$ & $1.4332 \pm 0.2626$ & $1.3978 \pm 0.3397$ & $1.6520 \pm 0.3474$ & $\begin{array}{r}-0.2542 \pm 0.2856 \\
(-7.9637,3.3007)\end{array}$ & 18 & 14 \\
\hline $\begin{array}{l}\text { Blue-winged teal } \\
\quad(\mathrm{N}=39)\end{array}$ & $1.1380 \pm 0.1382$ & $1.2610 \pm 0.1479$ & $0.8468 \pm 0.1524$ & $\begin{array}{r}\mathbf{0 . 4 1 4 2} \pm \mathbf{0 . 1 5 1 2} \\
(-1.1076,3.2672)\end{array}$ & 23 & 9 \\
\hline $\begin{array}{l}\text { N. Shoveler } \\
\quad(\mathrm{N}=41)\end{array}$ & $1.7498 \pm 0.3575$ & $1.9999 \pm 0.3428$ & $1.0977 \pm 0.3554$ & $\begin{array}{c}\mathbf{0 . 9 0 2 3} \pm \mathbf{0 . 4 3 5 2} \\
(-2.0593,15.1808)\end{array}$ & 27 & 7 \\
\hline
\end{tabular}


Table 5. Adjustment index for visibility of ducks counted on inner and outer transect widths during 2 periods, and difference between the inner and outer transect widths (mean \pm SE; range in parentheses; n) for 45 plots in North Dakota, 1995. Differences whose $95 \%$ confidence intervals do not include zero are highlighted in bold. For inner and outer transects widths, $\mathrm{N}=$ total number of basins observed; for difference, $\mathrm{N}=$ number of plots.

\begin{tabular}{|c|c|c|c|c|}
\hline Count & $\begin{array}{c}\text { Basin } \\
\text { Water Regime }\end{array}$ & $\begin{array}{c}\text { Outer Transect } \\
\text { Width }\end{array}$ & $\begin{array}{c}\text { Inner Transect } \\
\text { Width }\end{array}$ & $\begin{array}{c}\text { Mean Difference } \\
\text { (Inner-Outer) }\end{array}$ \\
\hline \multirow[t]{12}{*}{ 1-15 May } & \multirow[t]{3}{*}{ Temporary } & $2.94 \pm 0.40$ & $2.44 \pm 0.34$ & $-1.60 \pm 0.96$ \\
\hline & & $(1.05,28.57)$ & $(1.05,200.00)$ & $(-18.95,10.43)$ \\
\hline & & $\mathrm{N}=184$ & $\mathrm{~N}=670$ & $\mathrm{~N}=32$ \\
\hline & \multirow[t]{3}{*}{ Seasonal } & $3.31 \pm 0.87$ & $2.04 \pm 0.11$ & $-1.87 \pm 0.99$ \\
\hline & & $(1.05,200.00)$ & $(1.05,28.57)$ & $(-29.20,1.81)$ \\
\hline & & $\mathrm{N}=245$ & $\mathrm{~N}=1308$ & $\mathrm{~N}=35$ \\
\hline & \multirow[t]{3}{*}{ Semipermanent } & $2.99 \pm 0.57$ & $4.28 \pm 1.27$ & $0.27 \pm 0.90$ \\
\hline & & $(1.05,50.00)$ & $(1.05,200.00)$ & $(-10.52,21.63)$ \\
\hline & & $\mathrm{N}=108$ & $\mathrm{~N} ;=225$ & $\mathrm{~N}=29$ \\
\hline & \multirow[t]{3}{*}{ All basins } & $3.12 \pm 0.44$ & $2.39 \pm 0.18$ & $-4.33 \pm 1.21$ \\
\hline & & $(1.05,200.00)$ & $(1.05,200.00)$ & $(-30.43,5.73)$ \\
\hline & & $\mathrm{N}=537$ & $\mathrm{~N}=2203$ & $\mathrm{~N}=38$ \\
\hline \multirow[t]{12}{*}{16 May-5 June } & \multirow[t]{3}{*}{ Temporary } & $6.23 \pm 0.88$ & $4.09 \pm 0.29$ & $-3.03 \pm 1.51$ \\
\hline & & $(1.05,200.00)$ & $(1.05,66.67)$ & $(-29.34,9.50)$ \\
\hline & & $\mathrm{N}=241$ & $\mathrm{~N}=668$ & $\mathrm{~N}=33$ \\
\hline & \multirow[t]{3}{*}{ Seasonal } & $7.34 \pm 1.75$ & $3.04 \pm 0.21$ & $-5.20 \pm 2.11$ \\
\hline & & $(1.05,400.00)$ & $(1.05,100.00)$ & $(-63.88,4.89)$ \\
\hline & & $\mathrm{N}=310$ & $\mathrm{~N}=1313$ & $\mathrm{~N}=35$ \\
\hline & \multirow[t]{3}{*}{ Semipermanent } & $10.72 \pm 0.58$ & $6.14 \pm 0.88$ & $1.82 \pm 1.57$ \\
\hline & & $(1.05,400.00)$ & $(1.05,400.00)$ & $(-8.09,35.01)$ \\
\hline & & $\mathrm{N}=105$ & $\mathrm{~N}=240$ & $\mathrm{~N}=25$ \\
\hline & \multirow[t]{3}{*}{ All basins } & $7.47 \pm 1.17$ & $3.69 \pm 0.23$ & $-0.24 \pm 0.95$ \\
\hline & & $(1.05,400.00)$ & $(1.05,400.00)$ & $(-9.91,31.72)$ \\
\hline & & $\mathrm{N}=656$ & $\mathrm{~N}=2221$ & $\mathrm{~N}=37$ \\
\hline
\end{tabular}

at which basins are not included in the transect likely will be larger than found in our study. We believe the smallest basins recorded ( $0.01 \mathrm{ha})$ are biased high for 400-m transects because these basins are topological corrections of the GIS process, occurring when a basin in NWI data was divided by a road or other feature (Cowardin et al. 1995). A more realistic minimum basin size is 0.02 ha; these are simple points in NWI data that are then buffered during GIS processing (Cowardin et al. 1995:6) to provide a measure of area. We found no area-related bias in basins of this size.

The lack of differences in $\gamma$ for mallards, pintails, and gadwall indicated that these species responded equally to wetland conditions on inner and outer transect widths; thus, estimates of their numbers from 400$\mathrm{m}$ and $800-\mathrm{m}$ transect samples would be similar. Es-

Table 6. Proportion of wetland basins that had to be replaced from the sample of 800-m transects, proportion replaced for inner and outer transect widths, and the difference in proportion of basins dropped between inner and outer transect widths (mean \pm SE; range in parentheses) for 45 plots in North Dakota, 1995. Inner transect width is the same as the 400-m transect. Differences were calculated using square-root transformed values.

\begin{tabular}{|c|c|c|c|c|}
\hline $\begin{array}{c}\text { Basin Water } \\
\text { Regime }\end{array}$ & 800-m Transect & $\begin{array}{c}\text { Inner Transect } \\
\text { Width }\end{array}$ & $\begin{array}{c}\text { Outer Transect } \\
\text { Width }\end{array}$ & $\begin{array}{c}\text { Mean Difference } \\
\text { (Inner-Outer) }\end{array}$ \\
\hline Temporary & $\begin{array}{c}22.17 \pm 2.94 \\
(0.0-87.50)\end{array}$ & $\begin{array}{c}12.21 \pm 2.18 \\
(0.0-50.00)\end{array}$ & $\begin{array}{c}12.56 \pm 2.15 \\
(0.0-75.00)\end{array}$ & $\begin{array}{c}-2.98 \pm 4.43 \\
(-66.67,70.71)\end{array}$ \\
\hline Seasonal & $\begin{array}{c}19.05 \pm 1.79 \\
(0.0-51.67)\end{array}$ & $\begin{array}{c}13.65 \pm 2.69 \\
(0.0-71.43)\end{array}$ & $\begin{array}{c}10.26 \pm 1.43 \\
(0.0-45.23)\end{array}$ & $\begin{array}{c}1.59 \pm 3.63 \\
(-41.60,51.38)\end{array}$ \\
\hline Semipermanent & $\begin{array}{c}20.25 \pm 2.67 \\
(0.0-66.67)\end{array}$ & $\begin{array}{c}14.45 \pm 3.33 \\
(0.0-100)\end{array}$ & $\begin{array}{c}18.34 \pm 3.04 \\
(0.0-100)\end{array}$ & $\begin{array}{c}-8.10 \pm 4.32 \\
(-70.71,60.30)\end{array}$ \\
\hline All basins & $\begin{array}{c}19.35 \pm 1.80 \\
(0.0-52.00)\end{array}$ & $\begin{array}{c}12.78 \pm 2.40 \\
(0.0-62.00)\end{array}$ & $\begin{array}{c}10.20 \pm 1.05 \\
(0.0-33.00)\end{array}$ & $\begin{array}{c}0.31 \pm 3.34 \\
(-32.93,59.28)\end{array}$ \\
\hline
\end{tabular}


timates of shovelers and blue-winged teal, however, would be higher from 400-m transects because they showed a stronger response to wetland conditions on the inner than the outer transect width. These species may be responding to the higher occurrence of seasonal basins on the inner transect width (Kantrud and Stewart 1977) or perhaps the presence of nesting cover in the right-of-way.

The adjustment index calculated in our study was used to account for ducks occurring on portions of wetland basins that could not be viewed; a larger number equates to a larger portion of a basin that was obscured from view. Our results indicate that in the first count, there was a greater portion of basin area obscured from view on the outer transect width than the inner width, as one would expect. Adjustment indices were highly variable among plots and wetland regimes, and varied seasonally, likely due to vegetative growth obscuring more of the basin later in the season. Sauder et al. (1971) noted that dead vegetation affected observability in early counts, and new vegetative growth affected counts in the latter half of May; they also noted that fewer breeding pairs were observed as vegetative growth increased. The lack of differences in the number of basins that had to be replaced and weak differences in the adjustment index between inner and outer transect widths suggest that use of a wider transect is feasible for duck surveys, although feasibility of wider transects may become more limiting later in the growing season. The portion of more distant basins that can be viewed for counting ducks will depend on topography and woody cover.

We did not conduct duck counts at the plot level and thus are unable to address possible bias of transects relative to the larger landscape scale. Roadside strip transects probably overestimate duck abundance in the larger landscape where basin densities are biased high, as occurred on many of our plots. Use of $\gamma$ to adjust for spatial and temporal differences in wetland densities (water area), as developed by Cowardin et al. (1995), avoids this problem but requires data from GIS. Some studies have used a quadrat-based sampling design instead of strip transects for estimating waterfowl abundance (e.g., Cowardin et al. 1995), which helps avoid road-related biases reported here. However, ability to sample basins within quadrats may be limited by access to private land (Fellows and Buhl 1995). Biologists must consider the significance of bias relative to study objectives, landscape, and land accessibility when selecting quadrat or strip transects to evaluate duck abundance.

Our results indicate that estimates of basin densities and of shovelers and blue-winged teal, derived from 400-m transects located along roads, may be biased high relative to the larger landscape. Such biases are not of concern if duck and basin counts are used only as annual indices of abundance for detection of trends, as intended for state and federal breeding waterfowl surveys. The U.S. Fish and Wildlife Service reports annual duck and pond numbers as two separate indices, but these numbers often have been related to examine duck responses to water conditions (e.g., Johnson and Shaffer 1987, Batt et al. 1989, Miller and Duncan 1999). We caution that such relations derived from roadside transect data may not reflect the response of ducks to water conditions at a larger landscape scale because strip transects along roads provide biased representation of the larger landscape. Examination of correlations between duck and basin densities, using results from this study, indicates that 400$\mathrm{m}$ samples would yield a higher correlation coefficient than 800-m samples for all species combined ( $r=0.1921$ vs. 0.0831 , respectively) and higher correlations for each species except pintails, which occurred in relatively low numbers in our transects. When roadside ditches were excluded from pond counts, as done in WBPHS, correlation coefficients increased ( $r=0.2470$ and 0.2069 for $800-\mathrm{m}$ and $400-\mathrm{m}$ transects, respectively; all species combined). Transect survey protocol and landscape surrounding transects need to be examined to determine whether results reasonably represent conditions at a larger landscape scale. The WBPHS, conducted aerially, includes both road and non-road areas within its 400-m strip transect. Occurrence of biases related to transect width may be dependent on the proportion of the transect occurring along roads. Our data did not allow us to examine bias in non-road areas.

Methods used in this study differed from those of other transect surveys in that basins were included in the transect sample only if their centroid fell within the transect boundaries. We used the centroid method here for several reasons. First, it simplified sampling and reduced sources of error: because whole basins were sampled, we could objectively determine which basins were within the transect boundary and the area of each basin holding water. Second, for each basin, we related duck counts to area of the basin containing water and used this relation to extrapolate duck counts from the transect sample to a larger plot scale (following Cowardin et al. 1995 in Austin et al. 2001). A more common method used in other transect surveys (e.g., annual WBPHS; U.S. Fish and Wildlife Service and Canadian Wildlife Service 1987) is to count ducks on that portion of a basin that falls within the transect boundaries. This approach introduces error into both duck and water estimates and, in turn, to the relation between duck numbers and basin area. It introduces subjective error from observers in the field who must determine whether ducks observed on a basin are with- 
in the transect boundary and, if an adjustment index is used to correct for visibility, what portion of the basin can be observed. Because ducks are counted on only a portion of a basin in these situations, the data cannot be used to examine relations of ducks to basin area (Cowardin et al. 1995). Also, GIS processing is complicated by having to determine what portion of each basin falls within the transect boundary for estimating water area.

The prairie pothole landscape in North Dakota varies greatly among plots and among geographic regions relative to wetland characteristics (densities, areas, or water regimes) and in upland cover (Guntenspergen unpublished data). Geographic differences in soils and climate contribute to differences in landscape variables by influencing agricultural activities and landowners' abilities to drain wetlands. As demonstrated by the wide ranges in the variables measured here, bias in basin densities relative to the plot can vary greatly among areas. Similarly, differences in wetland density between inner and outer transect widths varied among plots. Graphical examination of the data showed no regional patterns for this study, but regional differences in landform can influence bias (e.g., topography affecting distribution of basins and roads). Millar (1981) compared habitat and wetland characteristics in 200-m roadside strips (one side of the road) to the remaining portion of that quarter section (64 ha) in the Prairie Pothole Region of Saskatchewan, Canada. Wetland differences between the two sampled areas often were influenced by land form (lacustrine, ground moraine, knob-and-kettle moraine, moraine, and sandy alluvial). In areas with very low basin densities, level of bias may be more erratic among study areas and dependent on road extent (what proportion of the area is sampled by the transect) and placement relative to basins.

In conclusion, 800-m roadside strip transects will have lower bias in estimating basin density and area and will more closely reflect waterfowl numbers at the landscape level than traditional 400-m wide transects. Area-related bias was relatively small for basins $<10$ ha, as occurred on our study plots. Biases and logistical limitations of using wider transect widths (e.g., ability to view basin due to topography and vegetation) will vary regionally. Whether biases we detected here are of concern depends on study objectives. Annual monitoring to detect trends in an area would not be affected by biases. However, bias related to transect width should be considered when transect data, whether for wetland basins or ducks, is used to represent larger landscape scales.

\section{ACKNOWLEDGMENTS}

Primary funding and support for this study was provided by the U. S. Geological Survey. Partial funding was provided by the U.S. Environmental Protection Agency (EPA), National Health and Environmental Effects Research Laboratory-Western Ecology Division through Interagency Agreement Number (DW 14936583). The manuscript has not been subjected to EPA's peer or administrative review process. L. Cowardin designed the sampling frame and procedures. W. Norling assisted with data collection and entry. R. Cox, S. Magill, and G. Sargeant provided statistical assistance. We thank T. Arnold, R. Cox, R. Johnson, R. Reynolds, T. Shaffer, and G. Smith for comments on earlier drafts.

\section{LITERATURE CITED}

Arnold, T. W. 1994. A roadside transect for censusing breeding coots and grebes. Wildlife Society Bulletin 22:437-443.

Austin, J. E., T. K. Buhl, G. R. Guntenspergen, W. Norling, and H. T. Sklebar. 2001. Duck populations as indicators of landscape condition in the prairie pothole region. Environmental Monitoring and Assessment. In Press.

Batt, B. D. J., M. G. Anderson, C. D. Anderson, C. D., and F. D. Caswell. 1989. The use of prairie potholes by North American ducks. p. 204-227. In A. Van der Valk (ed.) Northern Prairie Wetlands, Iowa State University Press, Ames, IA, USA.

Cowardin, L. M. and R. J. Blohm. 1992. Breeding population inventories and measures of recruitment. p. 423-445. In B. D. J. Batt, A. D. Afton, M. G. Anderson, C. D. Ankney, D. H. Johnson, J. A. Kadlec, and G. L. Krapu (eds.) Ecology and Management of Breeding Waterfowl. University of Minnesota Press, Minneapolis, MN, USA.

Cowardin, L. M., V. M. Carter, F. C. Golet, and E. T. LaRoe. 1979. Classification of wetlands and deepwater habitats of the United States. U.S. Fish and Wildlife Service, Biological Services Program, Washington, DC, USA. FWS/OBS-79/31.

Cowardin, L. M., D. H. Johnson, T. L. Shaffer, and D. W. Sparling. 1988. Applications of a simulation model to decisions in mallard management. U.S. Fish and Wildlife Service Technical Report 17.

Cowardin, L. M., T. L. Shaffer, and P. M. Arnold. 1995. Evaluations of duck habitat and estimation of duck population sizes with a remote-sensing-based system. National Biological Service Biological Science Report 2.

Dzubin, A. 1969. Assessing breeding populations of ducks by ground counts. p. 178-230. In Saskatoon Wetlands Seminar. Canadian Wildlife Service Report Series 6.

Fellows, D. P. and T. K. Buhl. 1995. Research access to privately owned wetland basins in the prairie pothole region of the United States. Wetlands 15:330-335.

Johnson, R. R. and K. F. Higgins. 1997. Wetland resources of eastern South Dakota. South Dakota State University, Brookings, SD, USA.

Johnson, R. R. and K. F. Higgins. 1998. Bias in quadrat-derived estimates of number of prairie wetlands. Wetlands 18:329-334.

Johnson, R. R., K. F. Higgins, D. E. Naugle, and J. A. Jenks. 1999. A comparison of sampling techniques to estimate number of wetlands. Wildlife Society Bulletin 27:103-108.

Johnson, D. H. and T. L. Shaffer. 1987. Are mallards declining in North America? Wildlife Society Bulletin 15:340-345.

Kantrud, H. A. and R. E. Stewart. 1977. Use of natural basins by breeding waterfowl in North Dakota. Journal of Wildlife Management 41:243-253.

Kiel, W. H., Jr., A. S. Hawkins, and N. G. Perret. 1972. Waterfowl habitat trends in the aspen parkland of Manitoba. Canadian Wildlife Service Report Series 18.

Millar, J. B. 1981. Evaluation of biases in habitat data collected from roadside transects. Canadian Wildlife Service unpublished report. Miller, M. R. and D. C. Duncan. 1999. The northern pintail in North 
America: status and conservation needs of a struggling population. Wildlife Society Bulletin 27:788-800.

Sauder, D. W., R. L. Linder, R. B. Dahlgren, and W. L. Tucker. 1971. An evaluation of the roadside technique for censusing breeding waterfowl. Journal of Wildlife Management 35:538-543.

Serie, J. R. and L. M. Cowardin. 1990. Use of social indices to predict reproductive success in canvasbacks. Journal of Wildlife Management 54:66-72.
U. S. Fish and Wildlife Service and Canadian Wildlife Service. 1987. Standard operating procedures for aerial waterfowl breeding ground population and habitat surveys in North America. Office of Migratory Bird Management, Laurel, MD, USA.

Manuscript received 25 April 2000; revisions received 30 June 2000; accepted 4 August 2000. 